\title{
PROTOTYPE ROBOT LENGAN DENGAN KONTROL JARAK JAUH MENGGUNAKAN BLUETOOTH HC-05 DAN KAMERA
}

\author{
Rozali Toyib ${ }^{1}$, Cahyo Saputra ${ }^{2}$ \\ 1,2 Teknik Informatika Fakultas Teknik Universitas Muhammadiyah Bengkulu \\ Jl. Bali Kota Bengkulu, telp (0736) 22765/fax (0736) 26161 \\ ${ }^{1}$ rozalitoyibeumb.ac.id \\ ${ }^{2}$ cahyosahputralgmail.com
}

Abstrak: Penggunaan Universal Serial Bus (USB) sebagai penghubung antara gamepad dengan robot, mengakibatkan jarak penggunaan robot menjadi terbatas sehingga penggunaannya hanya untuk jarak dekat, jika penggunaannya bisa melalui jarak jauh akan lebih baik karena tanpa harus mendekati robot namun dikarenakan menggunakan kabel sebagai penghubung antara Universal Serial Bus dengan robot menjadikan jarak penggunaannya menjadi terbatas. Maka pada penelitian ini dilakukan perubahan alat kontrol menggunakan smartphone dengan menggunakan modul bluetooth HC-05 sebagai penghubung antara robot dengan smarphone sehingga jarak yang dapat di gunakan pada pengontrolan lebih jauh dibandingkan penelitan sebelumnya yang hanya menggunakan gamepad sebagai alat kontrol dan masih menggunakan kabel pada penghubungannya, serta ditambahkan kamera first person view (FPV) untuk melihat keadaan sekitar sehingga dapat memantau keadaan sekitar.. Berdasarkan hasil pengujian : koneksi Bluetooth tanpa halangan jarak yang digunakan maksimal 1-10 meter dan waktu koneksi berbedah-bedah setiap meternya, penggunaan FPV memiliki daya jangkau maksimal 10 meter, diatas 10 meter gambar yang diterima tidak jelas, jika ingin menggunakan kamera first person view (FPV) harus menggunakan dua buah handphone.

Kata Kunci: robot, jarak, bluetooth HC-05, first person view (FPV)

Abstract: The use of the Universal Serial Bus (USB) as a liaison between the gamepad and the robot causes the distance to use the robot to be limited so that its use is only for short distances, if its use can go a long distance it will be better because it does not have to approach the robot but because it uses a cable as a link between Universal Serial Buses with robots limit the distance to use them. So in this study, a control device was changed using a smartphone using the HC-05 Bluetooth module as a liaison between the robot and the smartphone so that the distance that can be used for controlling is farther than in previous research which only used a gamepad as a control device and still used cables in the connection. and a first person view (FPV) camera is added to see the surroundings so that it can monitor the surrounding conditions. Based on the test results: Bluetooth connection without obstruction, the maximum distance used is 10 meters and the time of surgery, the use of FPV has a maximum coverage of 10 above that. received is unclear, if you want to use a first person view (FPV) camera you must use two cellphones.

Keywords: robot, distance, bluetooth HC-05, first person view (FPV)

\section{PENDAhUluan}

Teknologi robotik menggantikan peran manusia dengan peralatan-peralatan konvensional dengan peralatan canggih, salah satu produk robot yakni lengan robot, merupakan alat yang dibuat menyerupai lengan manusia, yang dapat digunakan untuk mengerjakan berbagai macam tugas yang biasa dilakukan oleh manusia dan bisa mengerjakan pekerjaan yang lebih rumit dan berbahaya karana dengan menggunakan lengan robot ini tidak membahayakan jiwa manusia kalau pekerjaan itu berhubungan zat-zat kimia atau yang 
Jurnal Pseudocode, Volume VIII Nomor 1, Februari 2021, ISSN 2355-5920, e-ISSN 2655-1845 www.ejournal.unib.ac.id/index.php/pseudocode

intensitas pekerjaan dalam waktu lama yang pada manusia menimbulkan kelelahan sudah menjadi kodratnya manusia, di samping itu sudah umum dalam pembuatan sebuah prototype robot yang dapat dikendalikan menggunakan gamepad sebagai interface-nya sehingga mudah digunakan karena sudah familiar dikenal orang umum, penggunaan Universal Serial Bus dipilih dibanding dengan langsung menyambungkan gamepad dengan microkontroler sudah menjadi standar pada kebanyakan alat teknologi, penggunaan Universal Serial Bus (USB)sebagai penghubung antara gamepad dengan robot, mengakibatkan jarak penggunaan robot menjadi terbatas sehingga penggunaannya hanya untuk jarak dekat, jika penggunaannya bisa melalui jarak jauh akan lebih baik karena tanpa harus mendekati robot namun dikarenakan menggunakan kabel sebagai penghubung antara Universal Serial Bus dengan robot menjadikan jarak penggunaannya menjadi terbatas.

Permasalahan di atas penulis ingin untuk membuat suatu prototype robot lengan dengan alat kontrol menggunakan smartphone dengan modul bluetooth $\mathrm{HC}-05$ sebagai penghubung antara robot dengan smartphone sehingga jarak yang dapat di gunakan pada pengontrolan lebih jauh serta ditambahkan kamera first person view (FPF) untuk memantau keadaan sekitarnya.

Pada penelitian terdahulu mobile robot yang dibuat menyerupai tank, dengan menggunakan akrilik sebagai body mobile robot yang menjadikan mobile robot terlihat menarik. Board arduino yang dilengkapi mikrokontroler AVR Atmega8 diprogram dengan menggunakan software codevisionavr. penggerak mobile robot menggunakan twin gearbox motor $d c$ yang ditempatkan pada posisi belakang mobile robot.
[1]. Perangkat mobile ini makin diminati oleh masyarakat pada saat ini. Selain itu adanya koneksi internet yang murah dan terjangkau semakin membuat perangkat ini seolah-olah menjadi barang yang harus dimiliki. Pada era kemajuan teknologi informasi saat ini kebutuhan akan informasi dan komunikasi yang cepat dan up to date sangatlah dibutuhkan untuk menunjang aktivitas pekerjaan sehari-hari, untuk perangkat mobile yang bias diakses online menggunakan koneksi internet sehingga akan memudahkan penggunanya untuk melakukan monitoring dari jarak jauh [2]. Aplikasi smartphone android dan mikrokontroller arduino melalui bluetooth, agar mempermudah penggunaannya dan menggantikan fungsi remote control, dengan menerapkan bluetooth pada handphone android yang terkoneksi ke modul bluetooth pada arduino, kemudian sistem dikontrol melalui handphone android untuk mengirimkan data ke arduino agar diolah untuk mengontrol kondisi motor, sehingga pintu pagar dapat dibuka dan dirtutup secara otomatis[3].

Penelitian bertujuan membuat sebuah prototype robot lengan dengan sistem kontrol android dengan kamera FPV untuk menggantikan peran manusia dalam pemindahan barang yang berbahaya seperti zat kimia atau benda-benda mudah meledak.

\section{LANDASAN TEORI}

\section{A. Robot}

Robot adalah alat mekanik yang dapat melakukan tugas fisik, baik menggunakan pengawas dan kontrol manusia, ataupun menggunakan program yang telah didefinisikan terlebih dulu (kecerdasan buatan) [4]. Robot dengan keistimewaan khusus sangat erat kaitannya dengan kebutuhan dalam dunia industri moder dan 
Jurnal Pseudocode, Volume VIII Nomor 1, Februari 2021, ISSN 2355-5920, e-ISSN 2655-1845 www.ejournal.unib.ac.id/index.php/pseudocode

Dewasa ini mereka semakin menuntut adanya suatu alat dengan kemampuan tinggi yang dapat membantu menyelesaikan pekerjaan manusia ataupun menyelesaikan pekerjaan yang tidak mampu diselesaikan manusia [5].

\section{B. Robot Lengan}

Manipulator, merupakan lengan yang memberikan gerakan robot untuk memutar, melipat, dan menjangkau objek. Manipulator digerakkan oleh actuator atau disebut sistem drive[6]. Robot tangan (robot arm) yang diciptakan untuk berbagai keperluan dalam meningkatkan produksi, memiliki bentuk lenganlengan, sendi yang dapat bergerak berputar (rotasi) dan memanjang/ memendek [7].

\section{Wirelles}

Wireless Local Area Network Jaringan lokal tanpa kabel atau WLAN adalah suatu jaringan area lokal tanpa kabel dimana media transmisinya menggunakan frekuensi radio (RF) dan infrared (IR), untuk memberi sebuah koneksi jaringan ke seluruh penggunadalam area disekitarnya[8]. Wifi adalah singkatan dari Wireles Fidelity, yaitu seperangkat standar yang digunakan untuk komunikasi jaringan lokal tanpa kabel (Wireless Local Area Network-WLAN). yang didasari pada spesifikasi IEEE 802.11[9].

\section{Kamera}

Pengertian kamera adalah sebuah alat yang di gunakan dalam kegiatan fotografi, kamera digunakan untuk membentuk atau merekam suatu bayangan ke dalam film atau memory card.[10].

\section{E. Bluetooth}

Bluetooth adalah sebuah teknologi komunikasi wireless (tanpa kabel) yang beroperasi dalam pita frekuensi 2,4 GHz unlicensed ISM (Industrial, Scientific and Medical) dengan menggunakan sebuah frequency hopping tranceiver yang mampu menyediakan layanan komunikasi data dan suara secara real-time antara hosthost bluetooth dengan jarak jangkauan layanan yang terbatas.[11]. Jarak jangkau dari gelombang radio hanya mencapai 1 meter sampai 100 meter karena itu disebut dengan short-range. Standar dari bluetooth dibuat oleh Bluetooth Special Interest Group [12]. Bluetooth dapat menembus dinding, kotak, dan berbagai rintangan lain walaupun jarak transmisinya hanya sekitar 30 kaki atau 10 meter [13].

\section{F. First Person View (FPV)}

First Person View (FPV) juga dikenal sebagai First Person Point Of View (POV) adalah kemampuan pengguna beberapa teknologi untuk melihat dari perspektif visual tertentu selain dari lokasi seseorang yang sebenarnya, seperti dilingkungan karakter dalam video game, drone, atau klien telemedicine[14]. First person view (FPV) system, seorang pilot drone dimudahkan dalam merekam dan mengambil gambar dari sudut tertentu dengan hasil yang terbaik dan sempurna[15]. FPV juga dikenal sebagai Remote Person View (RPV), atau piloting dengan video, adalah metode yang digunakan untuk mengontrol 16 kendaraan remote control dari driver atau pilot view point [16].

G. Arduino

Arduino adalah suatu perangkat prototype elektronik berbasis mikrokontroller yang fleksibel dan open-source, perangkat 
Jurnal Pseudocode, Volume VIII Nomor 1, Februari 2021, ISSN 2355-5920, e-ISSN 2655-1845 www.ejournal.unib.ac.id/index.php/pseudocode

keras dan perangkat lunaknya mudah digunakan [17]. Arduino UNO adalah sebuah board mikrokontroler yang didasarkan pada ATmega328 (datasheet) [18].

\section{H. Mikrokontroler}

Mikrokontroler adalah system mikroprosesor lengkap yang terkandung di dalam sebuah chip[19]. Secara harfiah bisa disebut pengendali kecil sebuah sistem elektronik yang sebelumnya banyak memerlukan komponen-komponen pendukung seperti IC TTL dan CMOS dapat direduksi/diperkecil dan akhirnya terpusat serta dikendalikan oleh mikrokontroler [20].

\section{Motor Servo}

Motor servo adalah gabungan antara motor DC yang telah dilengkapi dengan rangkaian umpan balik[21].

\section{J. Smartphone}

Smartphone ialah sebuah telepon seluler yang sangat canggih dan hampir menyerupai computer mini di mana didalamnya terdapat fitur-fitur yang dapat memudahkan penggunanya.[22].

\section{METOdE PENELITIAN}

\section{A. Metode Pengembangan Sistem}

Metode prototype adalah model pertama dari produk yang digunakan untuk men-testing konsep atau gambaran dari ide kita, langkah-langkah sebagai berikut :

\section{Pengumpulan kebutuhan}

Pelanggan dan pengembang bersama-sama mendefinisikan format dan kebutuhan kesseluruhan perangkat lunak, mengidentifikasikan semua kebutuhan, dan garis besar sistem yang akan dibuat.

\section{Membangun prototyping}

Membangun prototyping dengan membuat perancangan sementara yang berpusat pada penyajian kepada pelanggan (misalnya dengan membuat input dan contoh output-nya).

\section{Evaluasi protoptyping}

Evaluasi ini dilakukan oleh pelanggan apakah prototyping yang sudah dibangun sudah sesuai dengan keinginan pelanggan. Jika sudah sesuai maka langkah keempat akan diambil. Jika tidak, maka prototyping diperbaiki dengan mengulang langkah 1, 2 , dan 3 .

4. Mengkodekan sistem

Dalam tahap ini prototyping yang sudah disepakati diterjemahkan ke dalam bahasa pemrograman yang sesuai.

\section{Menguji sistem}

Setelah sistem sudah menjadi suatu perangkat lunak yang siap pakai, harus dites dahulu sebelum digunakan. Pengujian ini dilakukan dengan White Box, Black Box, Basis Path, pengujian arsitektur dan lain-lain

\section{Evaluasi Sistem}

Pelanggan mengevaluasi apakah sistem yang sudah jadi sudah sesuai dengan yang diharapkan . Jika sudah, maka langkah ketujuh dilakukan, jika belum maka mengulangi langkah 4 dan 5

\section{Menggunakan system}

Perangkat lunak yang telah diuji dan diterima pelanggan siap untuk digunakan.

\section{B. Flowchart}

Dua jenis metode penggambaran program flowchart ada dua, yaitu : Conceptual flowchart, menggambarkan alur pemecahan masalah secara global dan Detail flowchart, menggambarkan alur pemecahan masalah secara rinci. berikut ini merupakan Flowchart sistem kerja dari arduino, 
Jurnal Pseudocode, Volume VIII Nomor 1, Februari 2021, ISSN 2355-5920, e-ISSN 2655-1845

www.ejournal.unib.ac.id/index.php/pseudocode

motor servo, modul Bluetooth, roda gear box dari Robot :

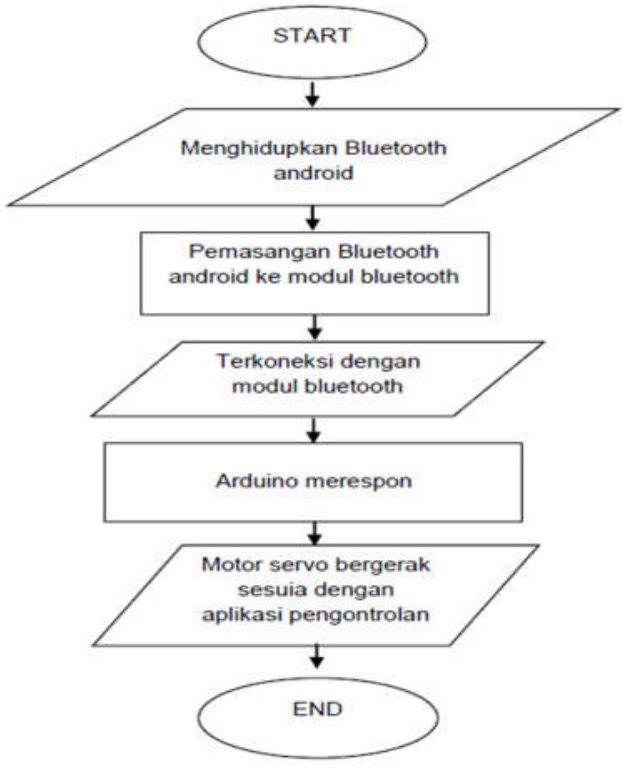

Gambar 1. Flowchart Sistem

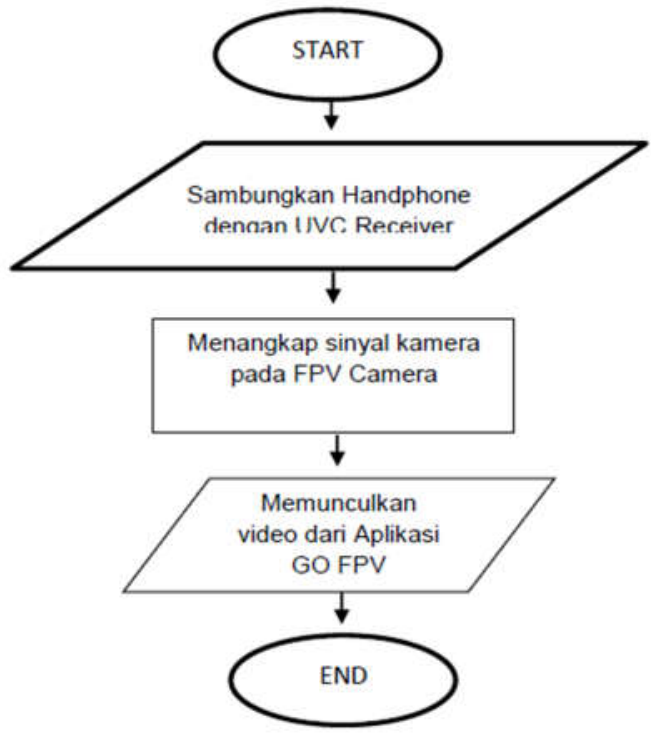

Gambar 2. Flowchart Kontrol Jarak Jauh

\section{Blok Diagram}

Dalam perancangan ini yang perlu diperhatikan adalah pemilihan komponenkomponen yang digunakan. Pemilihan komponen harus disesuaikan dengan kebutuhan sesuai dengan desain alat yang akan dibuat. Pada perancangan ini ada beberapa bagian yaitu Arduino Mega,
Motor DC, Modul Bluetooth, Roda Gearbox, dan baterai.

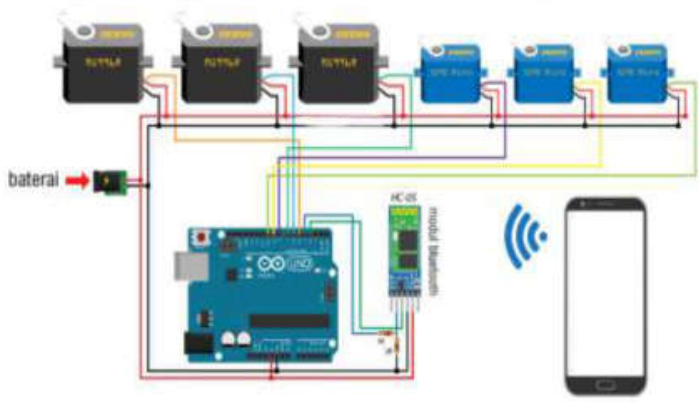

Sumber : Gita Tri Wardana, Teknik Komputer, AMIK MDP, Palembang Gambar 3. Rangkai Robot

Dari hasil skema diatas maka dirancang sebuah penempatan pada perangkat keras yang berupa, mikrokontroler Arduino Uno, motor servo, Module Bluetooth, roda gear box, dan Baterai pada Robot Lengan.

\section{HASIL DAN PEMBAHASAN}

A. Hasil

a. Merangkai Alat

Pada tahap pembuatan rangkaian ini yang dilakukan adalah mempersiapkan komponen yang akan digunakan seperti FPV kamera, arduino uno, relay, adaptor, catu daya/ baterai, lcd, module bluetooth, roda gear box(motor DC), saklar on/off dan kabel jumper. Pada arduino uno sudah disematkan mikrokontroler atmega 328, yang memiliki 14 pin input/output digital (6 output untuk PWM), dan 6 pin analog input. Rangkaian elektronik arduino memiliki beberapa komponen lainnya seperti IC regulator yang berfungsi sebagai kebutuhan rangkaian power supply. Sebagai sumber tegangan dalam rangkaian ini mengunakan adaptor 12 volt. Untuk motor servo mendapatkan input-an listrik sebesar $6 \mathrm{~V}$ dan menggunakan pin 6V untuk memberi input-an ke mikrokontroler/ 
Jurnal Pseudocode, Volume VIII Nomor 1, Februari 2021, ISSN 2355-5920, e-ISSN 2655-1845 www.ejournal.unib.ac.id/index.php/pseudocode

arduino, pada roda gear box sebagai daya menggunakan daya baterai untuk memberi gerak ,lcd sebagai tanda bahwa robot hidup atau mati , sedangkan untuk FPV Kamera itu terpisah, tidak terhubung langsung dengan arduino.

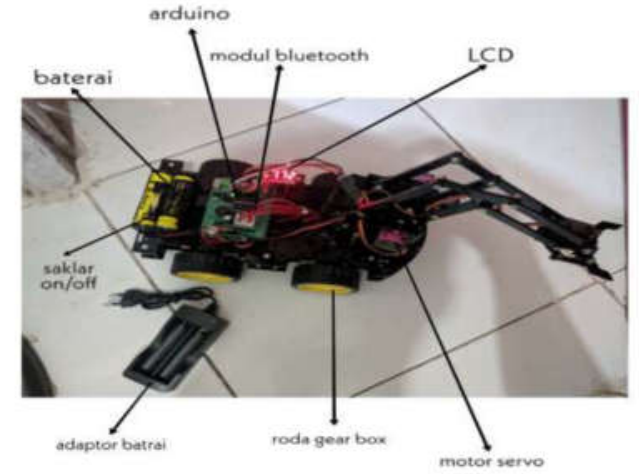

Gambar 4. Merangkai Alat

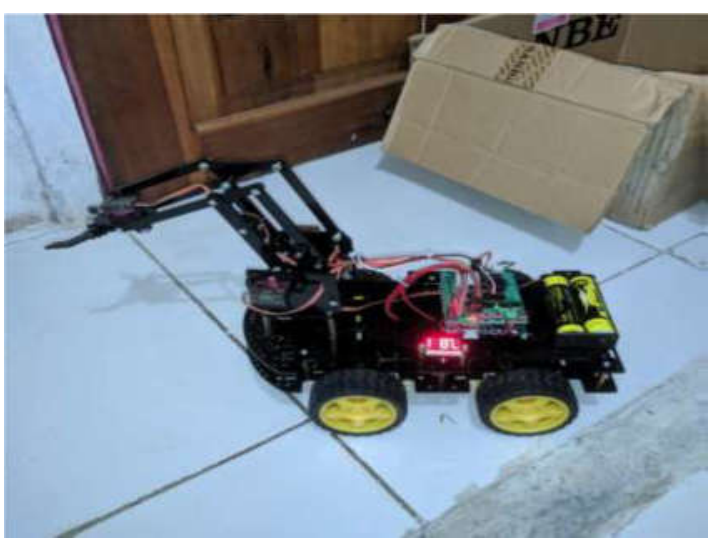

Gambar 5. Robot Lengan Semua Telah Terangkai

\section{b. FPV Kamera}

Pada bagian kamera, kamera terpisah dengan robot dipasang. FPV kamera dipasang diluar dari program arduino,dan digunakan jika berbeda ruangan dan berfungsi untuk menangkap gambar secara langsung, dan sebagai penerima gambar untuk di smartphone menggunakan UVC Receiver sebagai penghubung antara FPV kamera dan smartphone. FPV kamera menggunakan program yang ada di playstore sebagai penghubung antara kamera dengan smartphone, dikoneksikan menggunakan UVC receiver. Kamera tersebut di pasangkan pada robot sebagai alat komunikasi jarak jauh berupa gambar visual.

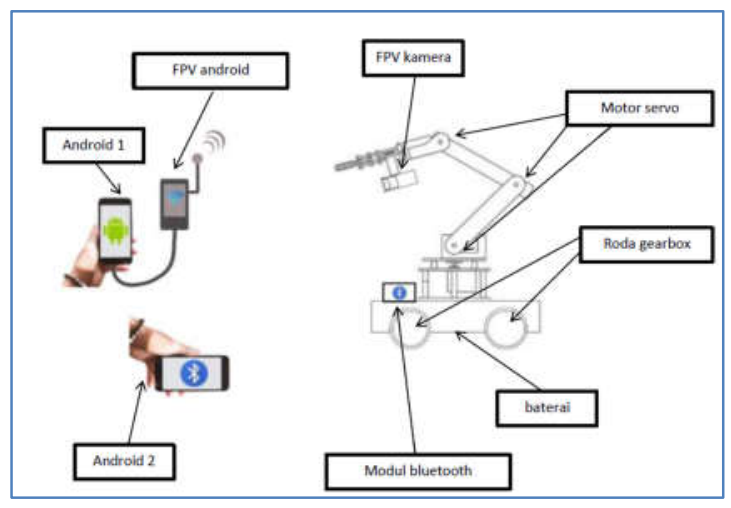

Sumber : Asmanditya Hibatullah, Program Studi Informatika Fakultas Komunikasi Dan Informatika Universitas Muhammadiyah Surakarta

Gambar 6. Kamera FPV

\section{c. Tahapan Pemrograman}

Program dibuat menggunakan Arduino.cc menggunakan bahasa $\mathrm{C}$ dan program inilah yang akan menjalankan perintah-perintah pada sistem dan alat. Kemudian program yang telah di-upload ke microkontroler akan melakukan proses pembacaan motor servo dan koneksi modul Bluetooth, dan dikoneksikan menggunakan aplikasi yang ada pada playstore, yaitu MeArm. Jika android terkoneksi dengan modul Bluetooth maka motor servo akan mengikuti perintah yang ada di aplikasi, jika android tidak terkoneksi dengan modul Bluetooth maka motor servo tidak akan mengikuti perintah yang ada di aplikasi. 
Jurnal Pseudocode, Volume VIII Nomor 1, Februari 2021, ISSN 2355-5920, e-ISSN 2655-1845

www.ejournal.unib.ac.id/index.php/pseudocode

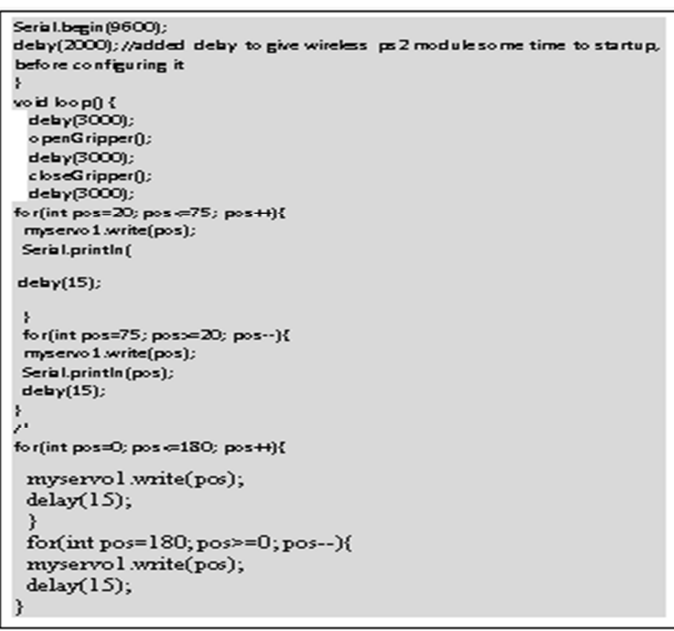

Gambar 7. Setting Program

B. Pembahasan

a. Pengujian Motor Servo

Pengujian kondisi motor servo dibagi menjadi dua yaitu saat kondisi low berarti motor servo dalam kondisi mati, sedangkan saat kondisi high motor servo bergerak. Tegangan motor diukur pada jalur yang menghubungkan antara output tegangan stepdown dengan ground pada volt $6 \mathrm{~V}$.

Tabel 1. Pengujian Motor Servo

\begin{tabular}{|c|c|c|}
\hline No & Kondisi Motor & Tegangan (V) \\
\hline \multirow{2}{*}{1} & 0 & 0 \\
\hline & 1 & 6.03 \\
\hline \multirow{2}{*}{2} & 0 & 0 \\
\hline & 1 & 6.04 \\
\hline \multirow{2}{*}{3} & 0 & 0 \\
\hline & 1 & 6.05 \\
\hline \multirow{2}{*}{4} & 0 & 0 \\
\hline & 1 & 6.05 \\
\hline \multicolumn{2}{|c|}{ Rata-rata kondisi : 0} & 0 \\
\hline \multicolumn{2}{|c|}{ Rata-rata kondisi : 1} & 6.05 \\
\hline
\end{tabular}

menjadi dua yaitu saat kondisi low berarti motor servo dalam kondisi mati, sedangkan saat kondisi high motor servo bergerak. Tegangan motor diukur pada jalur yang menghubungkan antara output tegangan stepdown dengan ground pada volt $6 \mathrm{~V}$.

Tabel 1, pengujian motor servo rata-rata kondisi low sebesar $0 \mathrm{~V}$, sedangkan ratarata kondisi high $6,05 \mathrm{~V}$.

b. Pengujian Motor DC

Pengujian kondisi motor DC dibagi menjadi dua yaitu saat kondisi low berarti motor servo kondisi mati, sedangkan saat kondisi high motor DC bergerak. Tegangan motor diukur pada jalur menghubungkan antara ouput ESCdengan ground pada volt $8,3 \mathrm{~V}$.

Tabel 2. Pengujian Motor DC

\begin{tabular}{|c|c|c|}
\hline No & Kondisi Motor & Tegangan (V) \\
\hline \multirow{2}{*}{1} & 0 & 0 \\
\cline { 2 - 3 } & 1 & 8,0 \\
\hline \multirow{2}{*}{2} & 0 & 0 \\
\cline { 2 - 3 } & 1 & 8,1 \\
\hline \multirow{2}{*}{3} & 0 & 0 \\
\cline { 2 - 3 } & 1 & 8,3 \\
\hline \multirow{2}{*}{4} & 0 & 0 \\
\cline { 2 - 3 } & 1 & 8,2 \\
\hline \multicolumn{2}{|c|}{ Rata-rata kondisi : 0} & 0 \\
\hline \multicolumn{2}{|c|}{ Rata-rata kondisi : 1} & 8,2 \\
\hline
\end{tabular}

Pengujian kondisi motor DC dibagi menjadi dua yaitu saat kondisi low berarti motor servo kondisi mati, sedangkan saat kondisi high motor DC bergerak. Tegangan motor diukur pada jalur menghubungkan antara ouput ESCdengan ground pada volt $8,3 \mathrm{~V}$. Tabel 2, pengujian motor DC rata-rata kondisi low sebesar $0 \mathrm{~V}$, sedangkan ratarata kondisi high $8,2 \mathrm{~V}$.

c. Pengujian Tranmisi Bluetooth

Pengujian modul Bluetooth dilakukan untuk melihat seberapa kemampuan jarak dan waktu yang diperlukan modul Bluetooth HC-05 dapat mengirim perintah dari smartphone pada arduino untuk menggerakkan motor servo dan motor dc. Pengujian dilakukan dengan smartphone dengan kondisi berbeda, yaitu pengujian akses smartphone tanpa halangan dan akses menggunakan halangan seperti tembok. Berikut hasil uji cobanya: 
Jurnal Pseudocode, Volume VIII Nomor 1, Februari 2021, ISSN 2355-5920, e-ISSN 2655-1845 www.ejournal.unib.ac.id/index.php/pseudocode

Tabel 3. Pengujian Konektivitas pada Bloutooth tanpa rintangan

\begin{tabular}{|l|l|l|l|c|}
\hline \multirow{2}{*}{ no } & \multirow{2}{*}{$\begin{array}{l}\text { Jarak } \\
\text { Meter }\end{array}$} & $\begin{array}{l}\text { Kondisi tanpa halangan } \\
\text { Bluetooth }\end{array}$ & $\begin{array}{l}\text { Kondisi } \\
\text { time (s) }\end{array}$ & $\begin{array}{c}\text { motor } \\
\text { servo }\end{array}$ \\
\cline { 3 - 4 } & 1 & terhubung & 1,56 & bergerak \\
\hline 2 & 2 & terhubung & 3,28 & bergerak \\
\hline 3 & 3 & terhubung & 5,41 & bergerak \\
\hline 4 & 4 & terhubung & 6,72 & bergerak \\
\hline 5 & 5 & terhubung & 8,07 & bergerak \\
\hline 6 & 6 & terhubung & 9,38 & bergerak \\
\hline 7 & 7 & terhubung & 10,18 & bergerak \\
\hline 8 & 8 & terhubung & 11,37 & bergerak \\
\hline 9 & 9 & terhubung & 12,62 & bergerak \\
\hline 10 & 10 & terhubung & 14,31 & bergerak \\
\hline 11 & & 11 meter atau tidak ada koneksi \\
\hline
\end{tabular}

Tabel 4. Pengujian Konektivitas pada Bloutooth dengan rintangan

\begin{tabular}{|c|c|c|c|c|}
\hline \multirow[b]{2}{*}{ no } & \multirow{2}{*}{$\begin{array}{l}\text { Jarak } \\
\text { Meter }\end{array}$} & \multicolumn{2}{|c|}{ Kondisi tanpa halangan } & \multirow{2}{*}{$\begin{array}{c}\text { Kondisi } \\
\text { motor } \\
\text { servo }\end{array}$} \\
\hline & & $\begin{array}{l}\text { Stauts } \\
\text { Bluetooth }\end{array}$ & $\begin{array}{l}\text { Piring } \\
\text { time (s) }\end{array}$ & \\
\hline 1 & 1 & terhubung & 2.97 & bergerak \\
\hline 2 & 2 & terhubung & 4,03 & bergerak \\
\hline 3 & 3 & terhubung & 6,03 & bergerak \\
\hline 4 & 4 & terhubung & 7,72 & bergerak \\
\hline 5 & 5 & terhubung & 10,34 & bergerak \\
\hline 6 & 6 & terhubung & 12,13 & bergerak \\
\hline 7 & 7 & terhubung & 13,35 & bergerak \\
\hline 8 & 8 & terhubung & 15,04 & bergerak \\
\hline 9 & 9 & terhubung & - & bergerak \\
\hline 10 & 10 & terhubung & - & bergerak \\
\hline 11 & & 11 meter & ada ko & \\
\hline
\end{tabular}

Dari hasil pengujian yang terdapat dalam tabel diatas dapat diterangkan bahwa :

a. Kondisi tanpa halangan

pada saat kondisi tanpa halangan dengan rentan jarak antara 1-10 meter meter bluetooth dapat terkoneksi dengan sempurna, namun pada jarak 11 meter lebih Bluetooth tidak mendapat koneksi apapun atau koneksi terputus b. Kondisi dengan halangan

Pada saat kondisi dengan halangan dengan rentan jarak 1-9 meter, status bluetooh dapat terkoneksi dengan sempurna, pada jarak 10 meter smartphone android tidak dapat menerima koneksi Bluetooth dikarenakan ada faktor penghalang tembok dan jarak jangkauan

c. Waktu koneksi Bluetooth

Setiap meternya mempunyai waktu koneksi yang berbeda-beda baik tanpa halangan maupun dengan halangan, semakin jauh jarak antara smartphone dengan modul Bluetooth maka semakin lama juga waktu yang dibutuhkan untuk konek ke modul Bluetooth HC pada robot lengan.

\section{d. Pengujian FPV Kamera}

Tahap selanjutnya adalah implementasi FPV kamera sebagai penglihatan jarak jauh pada robot lengan. Hasil proses implementasi yaitu uji pengiriman data FPV kamera pada smartphone. Berikut adalah tabel hasil uji FPV kamera.

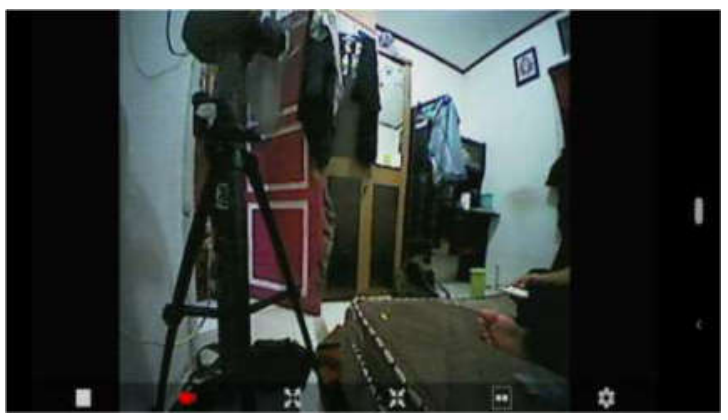

Gambar 6. Pengambilan video menggunakan FPV Kamera

Tahap selanjutnya adalah implementasi FPV kamera sebagai penglihatan jarak jauh pada robot lengan. Hasil proses implementasi yaitu uji pengiriman data FPV kamera pada smartphone. Kamera dan pengambilan data jarak berdasarkan posisi relavan. Berikut hasil pengambilan data FPV kamera pada robot lengan. 
Jurnal Pseudocode, Volume VIII Nomor 1, Februari 2021, ISSN 2355-5920, e-ISSN 2655-1845 www.ejournal.unib.ac.id/index.php/pseudocode

\begin{tabular}{|l|l|l|}
\hline \multicolumn{3}{|c}{ Tabel 5. Uji pengiriman Data FPV kamera } \\
\hline No & Jarak (Meter) & Pengiriman Data FPV Kamera \\
\hline 1 & 5 & Respon Lancar \\
\hline 2 & 10 & Respon Lancar \\
\hline 3 & 15 & Video Terputus-putus \\
\hline 4 & 20 & Video Terputus-putus \\
\hline 5 & 25 & Video Terputus \\
\hline 6 & 30 & Video Terputus \\
\hline
\end{tabular}

\section{F. Hasil Pengujian}

1. Pada koneksi Bluetooth tanpa halangan jarak yang digunakan maksimal 10 meter, jika melebih jarak maksimal maka koneksi akan terputus namun, jika terdapat halangan pada koneksi Bluetooth jarak yang digunakan maksimal 9, jika melebihi batas jarak maka tidak dapat terkoneksi dikarenakan terganggu oleh halangan tersebut berupa tembok, untuk waktu konektifitas Bluetooth, setiap meternya mempunyai waktu koneksi yang berbedabeda, semakin jauh jarak antara smartphone dengan modul Bluetooth maka semakin lama juga waktu yang dibutuhkan untuk konek ke modul Bluetooth $\mathrm{HC}$ pada robot lengan.

2. Penggunaan FPV kamera pada robot lengan memiliki daya jangkau terbatas, hanya 10 meter jika melebihi maka video dari kamera akan putusputus, dan jika sudah 25 meter maka kamera akan terputus, dan kameratersebut tidak menyatu dengan robot lengan, sehingga menggunakan smartphone lain untuk melihat video yang ada pada FPV Kamera.

3. Kelebihan dari prototype ini adalah penggunaannya yang sederhana menggunakan aplikasi yang ada pada playstore dan di program perintahnya menggunakan Arduino.cc, serta penggunaan kamera dapat membantu jika sedang berbeda

ruangan untuk mengambil/memindahkan barang.

4. Kekurangan dari Prototipe ini adalah harus menggunakan dua smartphne jika ingin menggunakan FPV kamera, namun jika tidak hanya perlu satu smartphone.

\section{KESIMPULAN}

Berdasarkan hasil pengujian adalah koneksi Bluetooth tanpa halangan jarak yang digunakan maksimal 10 meter, bila ada halangan maksimum 9 meter dan waktu koneksinya setiap meternya berbeda-beda, penggunaan FPV kamera robot memiliki jangkauan 1-10 meter dan bisa di pantau dari kamera handphone, prototype ini bisa menggunakan apliksi tersedia di play store dalam hal program Arduinonya, kelemahan dari prototype ini adalah diharusskan menggunakan 2 kamera smarphone jika mau menggunakan first person view (FPV).

\section{REFERENSI}

[1] I. W. S. I Made Suradana, "PENGENDALIAN MOBILE ROBOT MENGGUNAKAN PERSONAL COMPUTER DENGAN KONEKSI BLUETOOTH," J. Nas. Pendidik. Tek. Inform., vol. 2, pp. 2089-8673, 2013.

[2] Okkita Rizan and H. Hamidah, "Rancangan Aplikasi Monitoring Kamera CCTV Untuk Perangkat Mobile Berbasis Android," Teknol. Inform. dan Komput., vol. 3, p. $46,2016$.

[3] A. Syofian, "Pengendalian Pintu Pagar Geser Menggunakan Aplikasi Smartphone Android Dan Mikrokontroler Arduino Melalui Bluetooth," J. Tek. Elektro ITP, vol. 5, no. 2252, pp. 45-50, 2016.

[4] M. D. Tobi, "Rancang Bangun Robot Beroda Pemadam Api Menggunakan Arduino Uno Rev.1.3," Electro Luceat, vol. 1, no. 1, pp. 52-61, 2015, doi: 10.32531/jelekn.v1i1.16.

[5] RONI SETIAWAN, "PENGEMBANGAN ROBOT PENDETEKSI OBJEK BERDASARKAN WARNA DENGAN SENSOR KAMERA SEBAGAI MEDIA PEMBELAJARAN," 2012.

[6] dan H. D. Saharuddin, Ade Imam Surya Dipatih, "JPERANCANGAN PERANGKAT LUNAK PERGERAKAN LENGAN PADA ROBOT MELFA RV-2SD," vol. 14, pp. 1-11, 2019.

[7] A. Buchori and I. M. Sudana, "Rancang Bangun Miniatur Robot Lengan Menggunakan Mikrokontroler Atmega 8535," J. Tek. Elektro, vol. 6, no. 1, p. 7, 2014, doi: 10.15294/jte.v6i1.3567.

[8] R. Hartono and A. Purnomo, "Wireless Network 802.11," D3 Ti Fmipa Uns, vol. 1, no. 1, pp. 1-23, 2011. 
[9] D. Susianto and I. Yulianti, "Mengamankan Wireless dengan Menggunakan Two Factor, Password dan Mac Address Filtering," Expert J. Manaj. Sist. Inf. dan Teknol., vol. 5, no. 2, 2015, doi: 10.36448/jmsit.v5i2.720.

[10] S. Alvin, H. Bagus, and M. Janson, "Aplikasi eCommerce Dengan Fitur Top Product Menggunakan Metode Perceptron ( Studi Kasus Toko Kamera )," J. Ilmu Komput. dan Sist. Inf., pp. 210-213, 2018.

[11] D. F. Hermawan, I. Setiawan, and T. Andromeda, "Penggunaan Teknologi Java Pada Sistem Pengendali Peralatan Elektronik Melalui Bluetooth,” pp. 1-7, 2011.

[12] E. Susanti and N. Candra, "Perancangan Wirless Starter Kendaraan Bermotor Memanfaatkan Bluetooth Berbasis Arduino," Sigma Tek., vol. 1, no. 2, p. 207, 2018, doi 10.33373/sigma.v1i2.1528.

[13] H. Y. Sari, P. W. Ginta, and Y. S. H, "Papan Informasi Digital Dinamis Berbasis Atmega 8535 Dengan Media Perantara Bluetooth di Laboratorium Hardware Universitas Dehasen Bengkulu," J. Media Infotama, vol. 11, no. 2, pp. 149-158, 2015.

[14] P. ADIWIBOWO, "Sistem Kendali Kamera FPV ( First Person View ) 2 DOF Berbasis Gesture Kepala Menggunakan Sensor Accelerometer Dan Sensor Orientation," Univ. Teknol. Yogyakarta, 2019.

[15] A. F. Harista and S. Nuryadi, "Sistem Navigasi Quadcopter dan Pemantauan Udara," J. TeknoSAINS Ser Tek. Elektro, vol. 01, no. 01, pp. 1-22, 2018.

[16] M. S. Hak, R. Mardiyanto, and S. Suwito, "Pengembangan OSD (On Screen Display) dengan Penambahan Menu untuk Aplikasi pada Semi Autonomous Mobile Robot dengan Lengan untuk Mengambil Objek," J. Tek. ITS, vol. 5, no. 2, 2017, doi: 10.12962/j23373539.v5i2.16676.
[17] D. . Michael and D. Gustina, "Rancang Bangun Prototype Monitoring Kapasitas Air Pada Kolam Ikan Secara Otomatis Dengan Menggunakan Mikrokontroller Arduino," IKRA-ITH Inform., vol. 3, no. 2, pp. 59-66, 2019.

[18] A. Fatoni and D. B. Rendra, "Perancangan Prototype Sistem Kendali Lampu Menggunakan Handphone Android Berbasis Arduino," J. PROSISKO, vol. 1, no. September, pp. 23-29, 2014.

[19] I. Oktariawan, M. Martinus, and S. Sugiyanto, "Pembuatan Sistem Otomasi Dispenser Menggunakan Mikrokontroler Arduino Mega 2560," J. Ilm. Tek. Mesin FEMA, vol. 1, no. 2, p. 1, 2013

[20] H. N. Ahmad and Tedi Ardiyansyah, "PEMANFAATAN RFID (RADIO FREQUENCY IDENTIFICATION) UNTUK KEAMANAN PINTU LEMARI BERBASIS MIKROKONTROLER ATMEGA328," no. oktober, pp. 2252-4517, 2012.

[21] P. J. Rana Zahra, Thamrin, "Rancang Bangun Robot Humanoid Penari Gending Sriwijaya Menggunakan Modul Easyvr3," VoteTEKNIKA, vol. 5, no. 2, 2017.

[22] Juniver, V. Mokalu, N. N. Mewengkang, and J. P. M. Tangkudung, "Dampak Teknologi Smartphone Terhadap Perilaku Orang Tua di Desa Touure Kecamatan Tompaso," Acta Diurna, vol. 5, no. 1, pp. 1-9, 2016. 